\title{
Cocaine and Antidepressant-Sensitive Biogenic Amine Transporters Exist in Regulated Complexes with Protein Phosphatase 2A
}

\author{
Andrea L. Bauman, ${ }^{1}$ Subbu Apparsundaram, ${ }^{1}$ Sammanda Ramamoorthy, ${ }^{1}$ Brian E. Wadzinski, ${ }^{1}$ \\ Roxanne A. Vaughan, ${ }^{2}$ and Randy D. Blakely ${ }^{1}$ \\ ${ }^{1}$ Department of Pharmacology and Center for Molecular Neuroscience, Vanderbilt University School of Medicine, Nashville, \\ Tennessee 37232-6420, and 2Department of Biochemistry and Molecular Biology, University of North Dakota School of \\ Medicine and Health Sciences, Grand Forks, North Dakota 58202
}

Presynaptic transporter proteins regulate the clearance of extracellular biogenic amines after release and are important targets for multiple psychoactive agents, including amphetamines, cocaine, and antidepressant drugs. Recent studies reveal that dopamine (DA), norepinephrine (NE), and serotonin (5-HT) transporters (DAT, NET, and SERT, respectively) are rapidly regulated by direct or receptor-mediated activation of cellular kinases, particularly protein kinase C (PKC). With SERTs, PKC activation results in activity-dependent transporter phosphorylation and sequestration. Protein phosphatase 1/2A (PP1/PP2A) inhibitors, such as okadaic acid (OA) and calyculin A, also promote SERT phosphorylation and functional downregulation. How kinase, phosphatase, and transporter activities are linked mechanistically is unclear. In the present study, we found that okadaic acid-sensitive phosphatase activity is enriched in SERT immunoprecipitates from human SERT stably transfected cells. More- over, blots of these immunoprecipitates reveal the presence of PP2A catalytic subunit (PP2Ac), findings replicated using brain preparations. Whole-cell treatments with okadaic acid or calyculin A diminished SERT/PP2Ac associations. Phorbol esters, which trigger SERT phosphorylation, also diminish SERT/PP2Ac associations, effects that can be blocked by PKC antagonists as well as the SERT substrate 5-HT. Similar transporter/PP2Ac complexes were also observed in coimmunoprecipitation studies with NETs and DATs. Our findings provide evidence for the existence of regulated heteromeric assemblies involving biogenic amine transporters and PP2A and suggest that the dynamic stability of these complexes may govern transporter phosphorylation and sequestration.

Key words: serotonin; norepinephrine; dopamine; transporter; protein phosphatase $2 A$; protein kinase $C$; phosphorylation
The biogenic amine neurotransmitters dopamine (DA), norepinephrine (NE), and serotonin (5HT) are important modulators of multiple motor, cognitive, and autonomic processes in the brain and periphery (Feldman et al., 1997; Deutch and Roth, 1999). Active termination of aminergic signaling is mediated by plasma membrane transport proteins of the $\mathrm{Na}^{+} / \mathrm{Cl}^{-}$-dependent cotransporter gene family (Povlock and Amara, 1997; Nelson, 1998). Pharmacological blockade of DA transporter (DAT), NE transporter (NET), and serotonin transporter (SERT) proteins by psychostimulant (e.g., cocaine, amphetamine, methylphenidate) and antidepressant uptake inhibitors elevates extracellular neurotransmitter levels with subsequent augmentation of receptor stimulation (Barker and Blakely, 1995). Genetic ablation of DAT (Giros et al., 1996), NET (Xu et al., 2000), and SERT (Bengel et al., 1998) proteins reveals a profound contribution of appropriate transporter expression to presynaptic transmitter homeostasis and receptor stimulation. Recently, regulatory and coding polymorphisms have been identified in human SERT and NET genes and linked to affective disorders and autonomic disturbances, respectively (Lesch et al., 1996; Bengel et al., 1999; Shannon et al., 2000).

Although DAT, NET, and SERT proteins have been extensively

Received May 26, 2000; revised Aug. 4, 2000; accepted Aug. 8, 2000.

This work was supported by National Institutes of Health Grants MH58921 and DA07340 to R.D.B., HL07323 to S.A., GM51366 to B.E.W., and DA13147 to R.V., and a NARSAD Young Investigator Award to S.R. We thank Qiao Han for assistance with immunoprecipitations, plasmid preps, and cell transfections, Heather Farmer for assistance with phosphatase assays, and Dr. Greg Gerhardt for his guidance in amperometric studies.

Correspondence should be addressed to Dr. Randy D. Blakely, Center for Molec ular Neuroscience, 417 MRBII, Vanderbilt University Medical Center, Nashville, TN 37232-6420. E-mail: randy.blakely@mcmail.vanderbilt.edu.

Dr. Apparsundaram's present address: Department of Anatomy and Neurobiology, University of Kentucky, Lexington, KY 40506.

Dr. Ramamoorthy's present address: Department of Physiology and Neuroscience, 167 Ashley Avenue, Medical University of South Carolina, Charleston, SC 29425.

Copyright (C) 2000 Society for Neuroscience $0270-6474 / 00 / 207571-08 \$ 15.00 / 0$ characterized as drug targets, mechanisms affecting endogenous transporter regulation are poorly understood. DAT, NET, and SERT proteins, like other synaptic membrane proteins, are synthesized in the cell soma and transported to sites of utilization. Studies with irreversible antagonists (Fleckenstein et al., 1996; Kuhar et al., 1997) yield estimates of up to 2 weeks for biosynthetic recovery of DAT and SERT proteins in vivo after transporter inactivation, suggesting that more rapid, post-translational modulation of transporter expression is used to match altered demands for clearance. Indeed, recent studies with native preparations and heterologous model systems reveal receptor- and kinase-mediated changes in transport activity (Huff et al., 1997; Qian et al., 1997; Vaughan et al., 1997; Zhang et al., 1997; Apparsundaram et al., 1998a,b; Beckman et al., 1998; Melikian and Buckley, 1999), often supported by a change in transport capacity $\left(V_{\max }\right)$ with little or no change in apparent substrate affinity $\left(K_{\mathrm{m}}\right)$. Moreover, activation of protein kinase C (PKC) with phorbol esters has been shown to trigger DAT and SERT phosphorylation (Huff et al., 1997; Vaughan et al., 1997; Ramamoorthy et al., 1998a) and leads to a loss in transporter cell surface expression (Qian et al., 1997; Z hu et al., 1997; Pristupa et al., 1998; Daniels and Amara, 1999; Melikian and Buckley, 1999). Moreover, extracellular substrates appear to be able to influence transporter phosphorylation and/or trafficking in a receptorindependent manner (Bernstein and Quick, 1999; Duan et al., 1999; Ramamoorthy and Blakely, 1999), revealing an unexpected degree of regulation focused on quantitatively appropriate transport capacity.

Phosphorylation-dependent regulation of target proteins is a balance between the actions and localization of kinases and phosphatases. Recently, we demonstrated that inhibitors of protein phosphatase 1/2A (PP1/PP2A) such as okadaic acid (OA), calyculin A, and microcystin trigger SERT phosphorylation and reduce transport activity in human SERT-transfected human embryonic kidney (HEK)-293 cells (293-hSERT) (Ramamoorthy et al., 1998a). Sakai 
and coworkers (1997) also reported that calyculin A downregulates SERT in transfected COS-7 cells. Similar data have been presented for DAT (Huff et al., 1997; Vaughan et al., 1997) and NET proteins (Apparsundaram et al., 1998a,b). The catalytic subunit of PP2A (PP2Ac) is believed to associate with internalized $\beta_{2}$-adrenergic receptors $\left(\beta_{2} \mathrm{ARs}\right)$ after endosomal acidification (Krueger et al., 1997). Potential similarities in the kinase-dependent trafficking of biogenic amine transporters and $\beta_{2} \mathrm{ARs}$, and the pronounced phosphorylation of SERTs triggered by PP1/PP2A inhibitors, encouraged us to explore whether physical associations between transporters and PP2A might underlie transporter regulation. In the present study, we report evidence of catalytically active phosphatase associated with SERTs. Using coimmunoprecipitation techniques, we establish the existence of physical complexes containing biogenic amine transporters and PP2Ac proteins in native preparations and heterologous systems. These complexes, which can be observed in surfaceenriched preparations, are disrupted by PP1/PP2A inhibitors as well as PKC activators and can be stabilized by the SERT substrate 5-HT, suggesting that modulation of transporter/phosphatase associations is involved in regulated transporter phosphorylation and trafficking.

\section{MATERIALS AND METHODS}

Cell culture and transient transfections. hSERT stably transfected HEK-293 cells (293-hSERT) (Oian et al., 1997), hNET stably transfected LLC-PK1 cells (LLC-hNET) (Melikian et al., 1996), parental HEK-293, LLC-PK1, and COS-7 cells (American Type Culture Collection, Manassas, VA) were maintained in monolayer culture at $37^{\circ} \mathrm{C}, 5 \% \mathrm{CO}_{2}$ as described previously (Apparsundaram et al., 1998b; Ramamoorthy et al., 1998a). For transient transfections experiments, cells were plated at a density of 400,000 cells per well in six-well culture dishes. hSERT in pcDNA3 (Qian et al., 1997) or pcDNA3 vector DNA $(2 \mu \mathrm{g})$ was transfected using Fugene reagent as recommended by the manufacturer (Roche Diagnostics Corporation).

Preparation of cell and tissue extracts. Cells were grown in six-well plates (HEK-293 and 293-hSERT cells were grown on poly-D-lysine-coated plates) and solubilized with $400 \mu \mathrm{l}$ solubilization buffer $(10 \mathrm{~mm}$ Tris, $\mathrm{pH}$ 7.4, $150 \mathrm{~mm} \mathrm{NaCl}, 1 \mathrm{~mm}$ EDTA, 1\% Triton X-100) containing protease inhibitors $(1 \mathrm{mg} / \mathrm{ml}$ soybean trypsin inhibitor, $1 \mathrm{~mm}$ iodoacetamide, $250 \mu \mathrm{M}$ PMSF, $1 \mu \mathrm{M}$ pepstatin A, $1 \mu \mathrm{g} / \mathrm{ml}$ leupeptin, and $1 \mu \mathrm{g} / \mu \mathrm{l}$ aprotonin). The protein concentration of detergent extracts was determined using the Pierce BCL protein assay kit (Pierce, Rockford, IL) and bovine serum albumin as a standard. For preparation of midbrain synaptosomes, midbrains were rapidly dissected on ice. Tissue was homogenized using a Wheaton Instruments Teflon pestle/homogenizer in $5 \mathrm{ml}$ of $0.32 \mathrm{M}$ sucrose on ice, and synaptosomes were prepared by differential centrifugation as described (Robinson, 1998). Brain regions and vas deferens from 20-d-old male Sprague Dawley rats (Harlan) were homogenized (50 mM Tris, pH $7.4,5 \mathrm{~mm} \mathrm{KCl}, 300 \mathrm{~mm} \mathrm{NaCl}$, and $250 \mathrm{~mm}$ sucrose) with a Polytron homogenizer (Brinkman, $30 \mathrm{sec}, 25,000 \mathrm{rpm}$ ). Homogenates were centrifuged at $8000 \times g$ for $10 \mathrm{~min}$, pellets were discarded, and supernatants were centrifuged at $100,000 \times g$ for $45 \mathrm{~min}$ at $4^{\circ} \mathrm{C}$. Brain membranes were solubilized as described above for cells and synaptosomes. Vas deferens membranes were extracted with $300 \mathrm{~mm} \mathrm{NaCl}$, 10 mM HEPES, 2 mM DTT, and $1 \%$ Triton $\mathrm{X}-100, \mathrm{pH} 7.8$, for $2 \mathrm{hr}$ at $4^{\circ} \mathrm{C}$. Extracts were centrifuged at $20,000 \times g$ for $30 \mathrm{~min}$ at $4^{\circ} \mathrm{C}$. All studies with isolated animal tissues were performed in accordance with humane guidelines established by the Vanderbilt Institutional Animal Care and Use Committee under an approved protocol (M99007).

Immunoprecipitations and immunoblots. Immunoprecipitations and immunoblots were performed from detergent extracts of transiently transfected COS-7 and HEK-293 cells, 293-hSERT, LLC-hNET, midbrain synaptosomes, and tissue homogenates of rat brain and vas deferens as described previously (Ramamoorthy et al., 1998a). Supernatants were subjected to SDS-PAGE $(10 \%)$, electroblotted to polyvinylidene difluoride membrane (Amersham, Arlington Heights, IL), and probed with primary antibodies (see below). Blots were washed extensively with PBS containing $0.5 \%$ Tween and developed by enhanced chemiluminescence (ECL, Amersham). Multiple exposures of immunoblots were obtained to ensure development within the linear range of the film (Kodak X-AR). For some immunoprecipitations, extracts arose from cells that were biotinylated with sulfosuccinimidobiotin (NHS-biotin) (Pierce) before solubilization as described previously (Qian et al., 1997; Ramamoorthy et al., 1998b).

Antibodies. SERT immunoprecipitations were performed with SERTspecific sera CT2B (Qian et al., 1995b) or one of two new SERT antisera, 48 and 50 . The CT2B antisera is directed against the rSERT C terminus and recognizes rat, mouse, and human SERTs (Qian et al., 1995b; Ramamoorthy et al., 1998a). SERT antiserum 48 is a rabbit polyclonal antiserum raised against amino acids 596-662 (KERIIKSITPETPTEIPCGDIRMNAV) in the C terminus of rSERT, where the underlined residue designates the only divergent position comparing human and rat SERT. Antiserum 48 recognizes and immunoprecipitates human and rat SERT in transfected cells and native tissues (data not shown). SERT antiserum 50 is a rabbit polyclonal antiserum directed at amino acids
596-614 (KERIIKSITPETPTEIPC) in the C terminus of hSERT. Antiserum 50 was found to immunoprecipitate and recognize hSERT from transfected cells like antiserum 48, although it was less effective against rodent SERT (data not shown). NET immunoprecipitations were performed with rabbit polyclonal antiserum 43411 (Schroeter et al., 2000), directed against amino acids 585-607 (WERVAYGITPENEHHLVAQRDVR) in the C terminus of mouse NET (Fritz et al., 1998). This reagent recognizes both rat and human NET proteins. Rat dopamine transporters were immunoprecipitated using antibody 16 (Huff et al. 1997), directed against amino acids 42-59 (LTNSTLINPPQTPVEAQE) of rat DAT. For immunoblotting we used monoclonal PP2Ac (Transduction Laboratories, 1:2000), monoclonal $\mathrm{Na}^{+} / \mathrm{K}^{+}$ATPase (Affinity BioReagents, 1:2000), and monoclonal SERT (MAb Technologies, Inc., 1:10,000) antibodies, followed by HRP-conjugated goat anti-mouse IgG (Jackson Labs, 1:5000)

Phosphatase assays. Total detergent-soluble cell extracts or immunoprecipitated complexes were tested for the presence of okadaic acid-sensitive phosphatase activity. Immunoprecipitated complexes were washed three times with solubilization buffer and once with phosphatase assay buffer $(25$ $\mathrm{mm}$ Tris, pH 7.5, $1 \mathrm{~mm}$ EDTA, $1 \mathrm{~mm}$ EGTA, $1 \mathrm{mM}$ DTT, and $0.2 \mathrm{mg} / \mathrm{ml}$ BSA). Immunoprecipitates or whole-cell extracts were incubated with 50 $\mu \mathrm{l}$ phosphatase assay buffer containing $\left[{ }^{32} \mathrm{P}\right]$-labeled histone H1 (Jakes and Schlender, 1988) \pm 2 nM okadaic acid. Conditions were established such that no more than $10 \%$ of substrate was dephosphorylated. Assays were conducted in triplicate for $5 \mathrm{~min}$ at $30^{\circ} \mathrm{C}$ followed by trichloroacetic acid precipitation (Luo et al., 1998) and scintillation spectrometry.

Transport assays in native rodent tissues. Synaptosomal 5-HT transport assays were performed using $100 \mu \mathrm{g}$ synaptosomal protein/tube in Krebs'Ringer's HEPES (KRH) buffer containing (in $\mathrm{mM}$ ): $130 \mathrm{NaCl}, 1.3 \mathrm{KCl}, 2.2$ $\mathrm{CaCl}_{2}, 1.2 \mathrm{MgSO}_{4}, 1.2 \mathrm{KH}_{2} \mathrm{PO}_{4}, 10 \mathrm{HEPES}, \mathrm{pH} 7.4$, and $20 \mathrm{~nm}\left[{ }^{3} \mathrm{H}\right] 5-\mathrm{HT}$ [5-hydroxy- $\left[{ }^{3} \mathrm{H}\right]$ trifluoroacetate $(\sim 100 \mathrm{Ci} / \mathrm{mmol}$, Amersham $\left.)\right]$. Buffered synaptosomes were preincubated with or without modulators (e.g., OA norokadone) for $30 \mathrm{~min}$ at $37^{\circ} \mathrm{C}$ before initiation of assays with $\left[{ }^{3} \mathrm{H}\right] 5-\mathrm{HT}$ and then continued for $5 \mathrm{~min}$ at $37^{\circ} \mathrm{C}$. $\mathrm{Na}^{+}$dependence of transport was assessed by equimolar substitution of $\mathrm{Na}^{+}$with choline. Assays were terminated by transfer of samples to ice followed by rapid filtration over $0.3 \%$ polyethyleneimine-coated GF-B (Whatman, Maidstone, UK) filters on a Brandel Cell Harvester. Nonspecific uptake was defined as label accumulated in the presence of $1 \mu \mathrm{M}$ paroxetine (SmithKline Beecham Pharmaceuticals). Control experiments were performed with $50 \mathrm{~nm} \mathrm{~L}-[2,3-$ $3 \mathrm{H}$ lalanine $(\sim 61.0 \mathrm{Ci} / \mathrm{mmol}$, Amersham), and nonspecific uptake was defined through equimolar $\mathrm{Na}^{+}$substitution with choline. For assessment of NE transport activity, vas deferens from 20-d-old rats was minced in $0.32 \mathrm{M}$ sucrose into $100 \mu \mathrm{m}$ slices using an automated tissue chopper (McIlwain) and transferred to polypropylene tubes in KRH assay buffer (1 $\mathrm{ml}$ of KRH per vas deferens). This suspension (400 $\mu \mathrm{l} /$ tube) was incubated with either vehicle, $\beta$-phorbol 12-myristate 13 -acetate $(1 \mu \mathrm{M})$ or OA (1 $\mu \mathrm{M})$ for $30 \mathrm{~min}$ at $37^{\circ} \mathrm{C}$. Uptake assays $\left(500 \mu \mathrm{l}, 37^{\circ} \mathrm{C}\right.$ for $\left.10 \mathrm{~min}\right)$ were initiated by addition of $\left[{ }^{3} \mathrm{H}\right] \mathrm{NE}[1-[7,8-3 \mathrm{H}]$ noradrenaline (Amersham, 50 $\mathrm{nM}$ final concentration)]. Nonspecific uptake was defined using $1 \mu \mathrm{M}$ desipramine (Sigma, St. Louis, MO). Assays were terminated with addition of $3 \mathrm{ml}$ ice-cold KRH buffer followed by centrifugation of tissues at $3000 \times g$. Protein pellets were washed two times with ice-cold buffer and then denatured in $500 \mu \mathrm{l}$ of $1 \%$ SDS before protein assay and scintillation spectrometry. All transport assays were performed in triplicate, and mean values for specific uptake \pm SEM of at least three separate experiments were determined. Effects of drugs on transport activity were evaluated using a two-tailed Student's $t$ test, with $p<0.05$ considered significant.

Amperometric evaluation of catecholamine clearance. High-speed chronoamperometric measurements in rat vas deferens slices $(2 \mathrm{~mm}$ longitudinal thickness) were performed using an IVEC-10 system as described previously (Hoffman et al., 1998). DA was used to evaluate NET clearance function caused by enhanced sensitivity of electrodes for DA over NE and the recognized ability of NET proteins to transport DA with equivalent efficiency to NE (Buck and Amara, 1994). Electrodes with selectivity of $>300: 1$ for DA versus ascorbate were used in the experiment. Briefly, a single carbon fiber electrode $(100 \mu \mathrm{m}$ length $\times 30 \mu \mathrm{m}$ outer diameter; Quanteon SF-1) coated with Nafion (Sigma) and calibrated in vitro with DA $(2-10 \mu \mathrm{M})$ was attached to a single-barrel micropipette $(10-15 \mu \mathrm{m}$ tip) such that the distance between their tips was $200 \mu \mathrm{m}$. To record electrochemical signals, square wave pulses of 0.00 to $+0.55 \mathrm{~V}$ (oxidation) or -0.55 to $0.00 \mathrm{~V}$ (reduction) were applied to the carbon fiber electrode using IVEC-10. Two hundred nanoliters of $200 \mu \mathrm{M} \mathrm{DA}$ in $0.9 \% \mathrm{NaCl}$ and $100 \mu \mathrm{M}$ ascorbate were locally applied by pressure ejection using the PicoSpritzer II (Parker Hannifin Corp., Cleveland, OH). Parameters assessed were peak amplitude of the signal, $T_{80}$, the time for the signal to rise and decay by $80 \%$ from the peak amplitude, and clearance rate $\left(T_{\mathrm{c}}\right.$ in micrometers per second), defined as the change in the concentration of DA between the $T_{20}$ and $T_{60}$ time points (Cass and Gerhardt, 1995; Lin et al., 1997). For clearance experiments, rat vas deferens slices ( $2 \mathrm{~mm}$ in length) were perfused ( $1 \mathrm{ml} / \mathrm{min}$ ) with bicarbonate buffer containing (in $\mathrm{mm}$ ): 126 $\mathrm{NaCl}, 2.9 \mathrm{KCl}, 1.5 \mathrm{MgCl}_{2}, 2.2 \mathrm{CaCl}_{2}, 1.4 \mathrm{NaH}_{2} \mathrm{PO}_{4}, 10$ glucose, and 25 $\mathrm{NaHCO}_{3}$ pH 7.4, which was continuously bubbled with $95 \% \mathrm{O}_{2}$ and $5 \%$ $\mathrm{CO}_{2}$. The electrode-pipette assembly was positioned $\sim 100 \mu \mathrm{m}$ into the tissue. After a 30 min equilibration period, three DA pulses were applied at 5 min intervals. Subsequently, the tissue was perfused with buffer containing $1 \mu \mathrm{M} \mathrm{OA}, 1 \mu \mathrm{M}$ desipramine, or $0.3 \mu \mathrm{M}$ GBR12909 for $30 \mathrm{~min}$, 


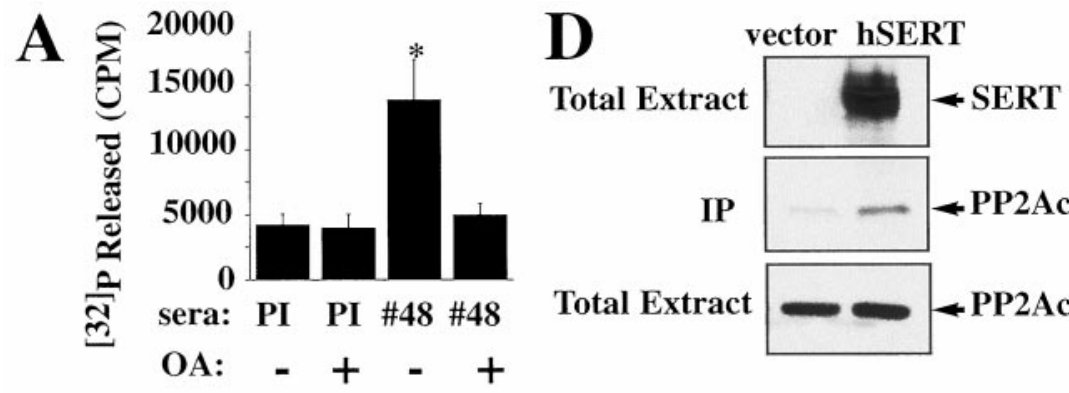

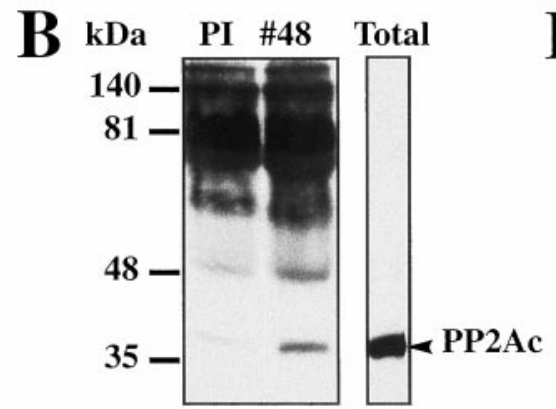

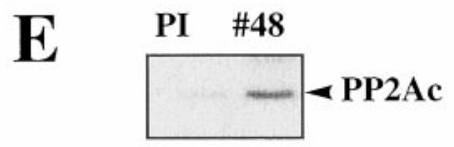

El.
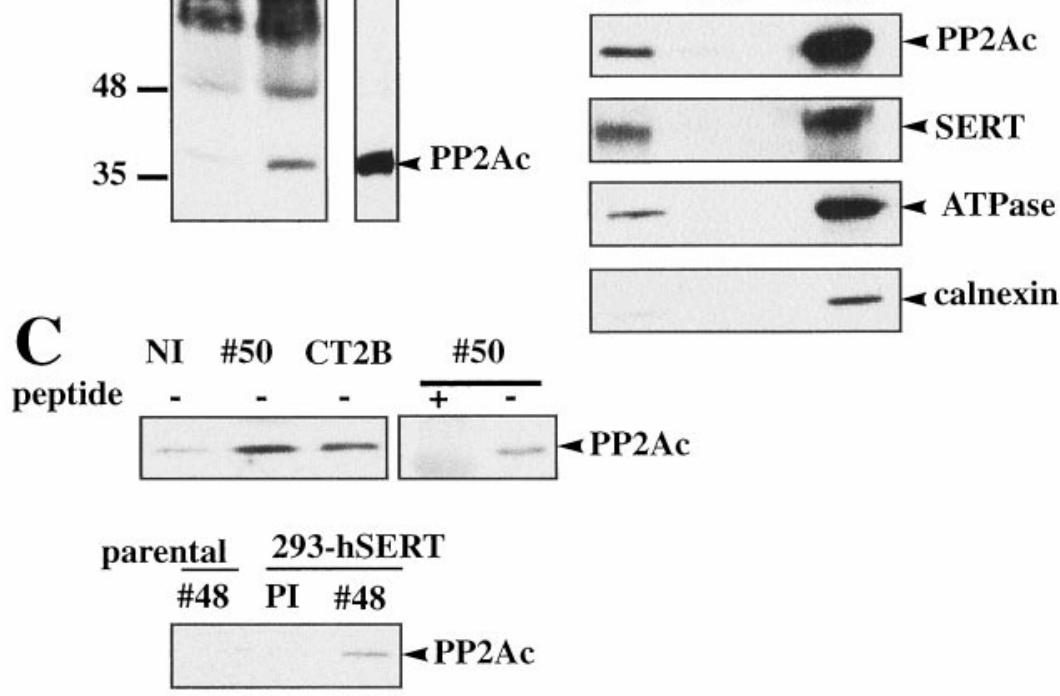

Figure 1. Identification of SERT/PP2Ac association in transfected cells. $A$, OA-sensitive phosphatase activity is present in SERT immunoprecipitates. Phosphatase activity was measured in SERT (\#48) immune complexes $(n=3)$, as described in Materials and Methods, and compared with activity found with nonimmune sera $(* p<0.05$, Student's $t$ test). $B$, PP2Ac coimmunoprecipitates with hSERT in stably transfected HEK-293 cells. Total cell extracts from 293 hSERT cells $(250 \mu \mathrm{g})$ were immunoprecipitated overnight with SERT immune sera (\#48) or preimmune sera $(P I)$, and the resulting blot was probed with PP2Ac monoclonal antibody as described in Materials and Methods. $C$, Multiple SERT antisera immunoprecipitate PP2Ac. Top panel, SERT/PP2Ac complexes immunoprecipitated using multiple SERT antisera. In addition to $\mathrm{Ab} \# 48$, PP2Ac immunoreactivity was detected in immunoprecipitates using either SERT sera \#50 or CT2B (lanes 2, 3) but was significantly reduced in immunoprecipitations using nonimmune sera $(N I)$ or \#50 sera preabsorbed with $100 \mu \mathrm{g} / \mathrm{ml}$ peptide. Bottom panel, PP2Ac immunoreactivity is enriched in 293-hSERT cells over parental HEK-293 cells. Levels of PP2Ac in parental HEK-293 cell immunoprecipitates were equivalent to that seen with preimmune serum. D, SERT/PP2Ac immune complexes (Ab \#48) are formed in COS-7 cells transiently transfected with hSERT cDNA as compared with pcDNA3 vector. $E, \mathrm{SERT} / \mathrm{PP} 2 \mathrm{Ac}$ complexes are detected in plasma membrane-enriched preparations. 293-hSERT cells were biotinylated using membrane-impermeant NHS-biotin and surface proteins isolated on monomeric streptavidin beads as described in Materials and Methods. Associated proteins were eluted with $2 \mathrm{~mm}$ free biotin and immunoprecipitated overnight. Blots of immunoprecipitates reveal SERT/PP2Ac complexes that were diminished in immunoprecipitations using preimmune sera $(P I)$. The bottom panels show representative blots of proteins from the eluted fractions, the last wash $(L W)$, or total extracts probed with antibodies against PP2Ac, SERT, $\mathrm{Na}^{+} / \mathrm{K}^{+}$ATPase (as a plasma membrane marker), or calnexin (as an intracellular marker) used to determine plasma membrane-enriched fractions. Quantitation of protein immunoreactivities reveals a fivefold enrichment of $\mathrm{Na}^{+} / \mathrm{K}^{+}$ATPase over calnexin, consistent with predominant recovery of cell-surface proteins in biotinylated fractions. and DA pulses were repeated. Values obtained are the means of at least three experiments \pm SEM.

\section{RESULTS}

\section{SERT immunoprecipitates contain okadaic acid- sensitive phosphatase activity and PP2Ac immunoreactivity}

Acute treatment (5-60 min) of hSERT stably transfected HEK-293 cells (293-hSERT) with the PP1/PP2A inhibitors OA, calyculin A, or microcystin results in the phosphorylation of SERT proteins and a reduction in 5-HT transport activity (Ramamoorthy et al., 1998a). Whole-cell extracts of 293-hSERT cells were found to contain OA-sensitive phosphatase activity that could be eliminated by exposure of cells to OA ( $1 \mu \mathrm{M}, 30 \mathrm{~min})$ before solubilization (data not shown). Phosphatase assays performed with SERT immune complexes from 293-hSERT cells revealed OA-sensitive phosphatase activity that was absent from control immunoprecipitations (Fig. 1A). Although 2 nм OA blocks $\sim 50 \%$ of phosphatase activity measured in whole-cell extracts, a similar treatment of SERT immunoprecipitates fully abolished coprecipitated phosphatase activity. Moreover, blots of SERT immunoprecipitates from 293 hSERT cells using a monoclonal PP2Ac antibody (Fig. $1 B-D$ ) reveal the presence of a $36 \mathrm{kDa}$ band consistent with the expected size for PP2A catalytic subunit (Cohen, 1989; Luo et al., 1998). Very little PP2Ac was detected in immune complexes from parental HEK-293 cells or in immunoprecipitates performed with preimmune sera, normal rabbit sera, or peptide-absorbed immune sera. Moreover, we were able to identify elevated hSERT/PP2Ac associations in hSERT-transfected COS-7 (Fig. 1E) and HEK-293 cells (data not shown) relative to vector-transfected cells. Moreover, phosphatase assays conducted with SERT immunopre- cipitates of transfected COS-7 cells reveal a $77 \pm 25 \%(n=3)$ increase in recovered phosphatase activity as compared with vector-transfected cells. Finally, hSERT immunoprecipitations from biotinylated fractions revealed significant PP2Ac immunoreactivity, suggesting that plasma membrane SERTs form stable associations with the phosphatase (Fig. 1D).

\section{SERT/PP2Ac complexes in native tissue}

Consistent with data reported in 293-hSERT cells (Ramamoorthy et al., 1998a), treatment of mouse midbrain synaptosomes with OA results in a reduction in 5-HT transport activity, whereas treatment with the inactive OA analog, 1-norokadone, failed to alter 5-HT transport (Fig. 2A). Because OA caused no significant alteration in transport of $\left[{ }^{3} \mathrm{H}\right]$ alanine (data not shown), another $\mathrm{Na}^{+}$dependent transport activity in synaptosomes, alterations in 5-HT transport do not appear to be a result of a general disruption in the electrochemical gradient supporting transport. To determine whether SERT/PP2Ac complexes also exist in vivo, we blotted SERT immunoprecipitates from mouse midbrain and synaptosomes for PP2Ac. As with 293-hSERT cells, PP2Ac was detected in immune complexes (Fig. 2B), findings replicated with multiple SERT antisera (data not shown). Similar findings of SERT/PP2Ac association were also evident in immunoprecipitations from rat tissues (Fig. 2C). Evaluation of extracts from multiple rat brain regions and peripheral tissues indicates that the degree of recovery of PP2Ac in SERT immunoprecipitates generally correlates with the pattern of SERT protein distribution. Thus we found a greater abundance of PP2Ac in immune complexes from midbrain and cortex where SERT protein is abundant and less immunoprecipitation of PP2Ac in the cerebellum, which expresses lower levels of the transporter (Qian et al., 1995b; Bengel et al., 1997). Immuno- 
A

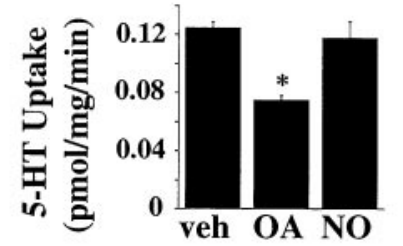

B

B

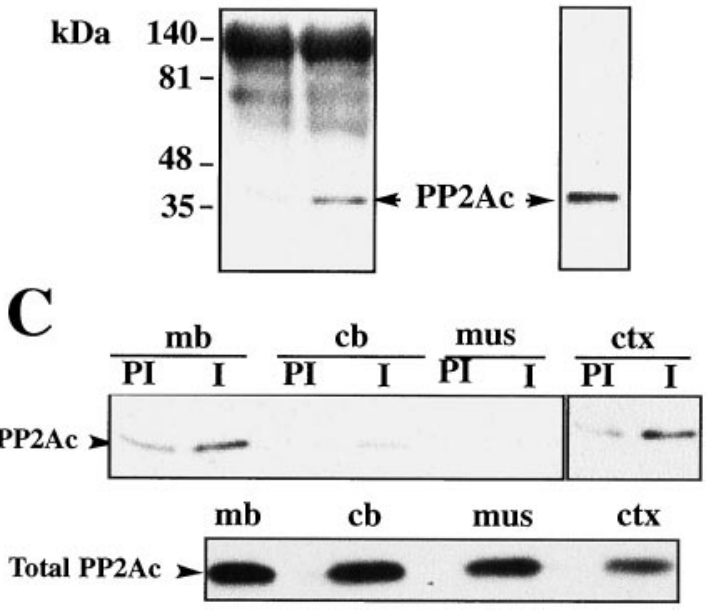

Figure 2. Identification of SERT/PP2Ac associations in native tissues. $A$, Midbrain synaptosomes $(100 \mu \mathrm{g})$ were preincubated with vehicle (DMSO, $v e h), O A(1 \mu \mathrm{M})$, or 1 -norokadone $(N O, 1 \mu \mathrm{M})$ for $30 \mathrm{~min}$ at $37^{\circ} \mathrm{C}$ and then assayed for 5-HT ( $2 \mu \mathrm{M}$ final, $10 \mathrm{~min}$ ) uptake as described in Materials and Methods. Data are the average \pm SEM of three separate experiments. Nonspecific uptake was defined as the uptake in the presence of $0.1 \mu \mathrm{M}$ paroxetine and subtracted from the total accumulation to yield specific uptake. ${ }^{*} p<0.05$, Student's $t$ test. $B$, SERT/PP2Ac complexes identified in mouse midbrain synaptosomes. Adult mouse midbrain synaptosomal protein $(500 \mu \mathrm{g})$ was immunoprecipitated overnight with preimmune sera (lane 1) or SERT CT2B sera (lane 2), and the resulting Western blot was probed for PP2Ac. Right panel, Immunoblot of total mouse midbrain synaptosomal protein probed with the PP2Ac monoclonal antibody. $C$, Coimmunoprecipitation of PP2Ac from rat tissues. Representative blot showing PP2Ac immunoreactivity recovered from immunoprecipitations from $500 \mu \mathrm{g}$ rat midbrain $(\mathrm{mb})$ (lanes 1,2$)$, cerebellum $(\mathrm{cb})$ (lanes 3, 4 ) skeletal muscle (mus) (lanes 3, 4), or cortex (ctx) (lanes 5, 6) using SERT immune sera CT2B $(I)$ or preimmune sera $(P I)$. Bottom panel shows similar levels of PP2Ac in all tissue extracts.

precipitation of PP2Ac was absent from non-SERT-expressing tissue (skeletal muscle), although all regions expressed comparable levels of PP2Ac in total extracts (Fig. 2C).

\section{Phosphatase inhibition disrupts PP2Ac/SERT association}

Significant decreases in transport activity and concomitant increases in SERT phosphorylation are evident in 293-hSERT cells treated with the PP1/PP2A inhibitors OA, calyculin A, and microcystin but not with the PP2B inhibitor cyclosporine A (Ramamoorthy et al., 1998a). We asked whether the SERT/PP2Ac complex displays a similar sensitivity to phosphatase inhibition. Treatment of 293-hSERT cells with $1 \mu \mathrm{M}$ OA for $30 \mathrm{~min}$, which produces a threefold increase in SERT phosphorylation (Ramamoorthy et al., 1998a), abolished OA-sensitive phosphatase activity in whole-cell extracts (data not show) and disrupted SERT-PP2Ac associations (Fig. 3A). The decrease in coimmunoprecipitated PP2Ac was not seen when cells were treated with 1-norokadone but was evident using calyculin A, another PP1/PP2A inhibitor. Tautomycin, an inhibitor more selective for PP1 (Favre et al., 1997), and the PP2B inhibitor cyclosporine A failed to alter the association. The effect of whole-cell OA treatment on SERT/PP2Ac complex stability displayed an $\mathrm{EC}_{50}$ of $\sim 100 \mathrm{~nm}$ OA (Fig. 3B), consistent with the known membrane permeability of OA (Favre et al., 1997). Coimmunoprecipitation studies from OA-treated mouse midbrain syn-
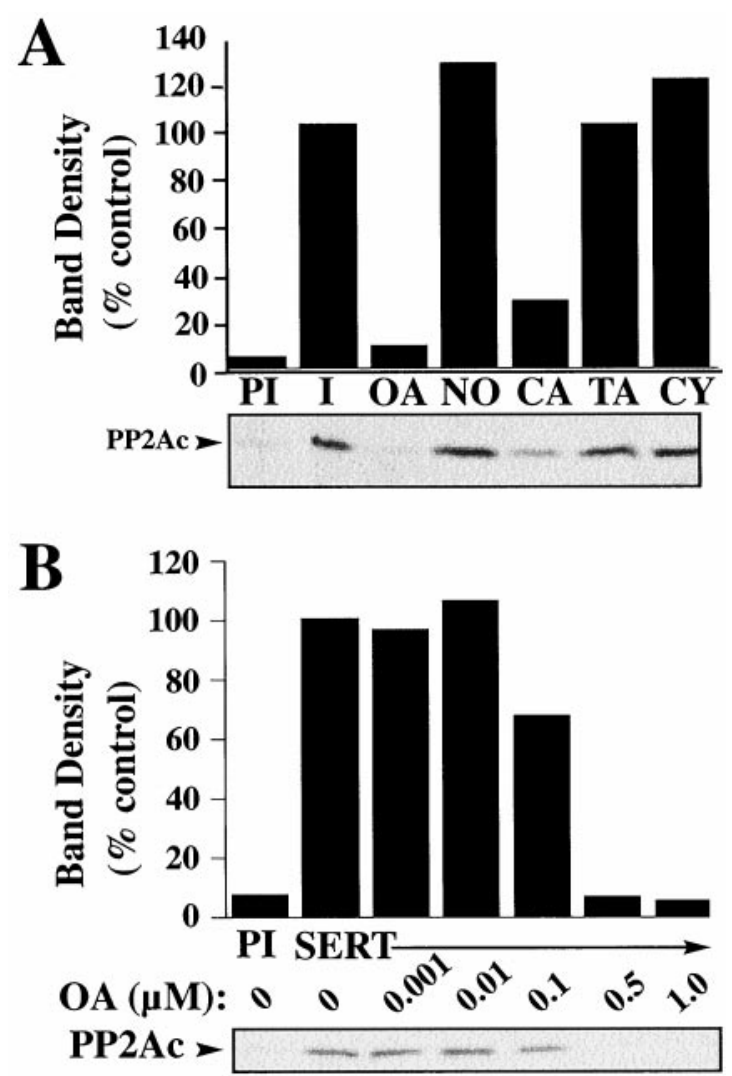

OA $(\mu \mathrm{M}): \quad 0 \quad 0.5 \quad 1.0$
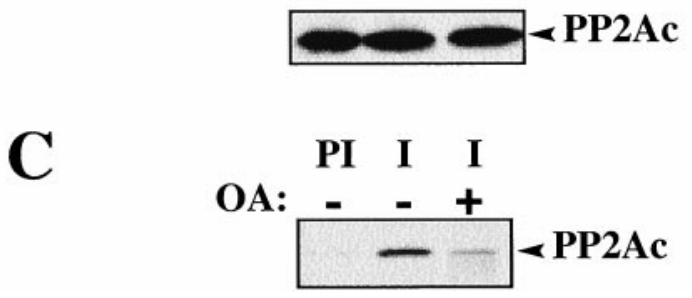

Figure 3. PP2A inhibitors regulate PP2Ac/SERT associations in intact cells. $A$, 293-hSERT cells treated with various phosphatase inhibitors display inhibitor-specific effects on SERT/PP2Ac associations. 293-hSERT cells were incubated for $30 \mathrm{~min}$ at $37^{\circ} \mathrm{C}$ in the presence or absence of phosphatase inhibitors: $O A(1 \mu \mathrm{M})$, norokadone $(N O, 1 \mu \mathrm{M})$, calyculin $\mathrm{A}$ $(C A, 1 \mu \mathrm{M})$, tautomycin $(T A, 1 \mu \mathrm{M})$, or cyclosporine A $(C Y, 5 \mu \mathrm{M})$. Detergent extracts were immunoprecipitated with either SERT 48 immune or preimmune sera, and the resulting blot was probed for PP2Ac. B, Dose-response of OA for the disruption of SERT/PP2Ac association in whole-cell preparations. 293-hSERT cells were treated with increasing concentrations of $\mathrm{OA}$ for $30 \mathrm{~min}$ at $37^{\circ} \mathrm{C}$. Detergent extraction, immunoprecipitation with SERT antibody 48, and autoradiography were performed as described in Materials and Methods. Bottom panel shows a representative Western blot of total PP2Ac protein from 293-hSERT cell extracts treated with $0,0.5$, or $1.0 \mu \mathrm{M}$ OA. $C$, OA pretreatment diminishes PP2Ac in SERT immunoprecipitates from mouse midbrain synaptosomes. Synaptosomes were incubated with $1 \mu \mathrm{M}$ OA for $30 \mathrm{~min}$ and immunoprecipitated with either preimmune $(P I)$ or SERT immune sera (48), and the resulting blot was probed for PP2Ac as described in Materials and Methods.

aptosomes also revealed a loss in SERT-associated PP2Ac relative to vehicle-treated samples (Fig. $3 C$ ). Our findings indicate that OA may compete with SERT for the active site of PP2Ac (Gupta et al., 1997) or that SERT/PP2Ac associations are sensitive to inhibitorinduced conformational changes in PP2Ac. Alternatively, kinase activation subsequent to phosphatase inhibition could trigger disassembly.

\section{PKC activators diminish hSERT/PP2Ac association}

PKC activators, such as phorbol 12-myristate 13 -acetate ( $\beta$-PMA) and indolactam $\mathrm{V}$, have been shown to reduce 5-HT transport 
activity (Qian et al., 1997; Ramamoorthy et al., 1998a) and induce phosphorylation and internalization of SERT in 293-hSERT cells (Qian et al., 1997; Ramamoorthy et al., 1998a). The ability of PKC activators to trigger SERT phosphorylation may be attributable to direct SERT phosphorylation by PKC, providing a signal for transporter internalization (Qian et al., 1997). Alternatively, PKC activation may disrupt preexisting SERT/PP2Ac complexes, exposing sites for transporter phosphorylation. To determine whether PKC activators influence SERT/PP2Ac associations, 293-hSERT cells were treated for $30 \mathrm{~min}$ with $1 \mu \mathrm{M} \beta$-PMA, conditions that lead to an increase in the phosphorylation of SERT by five- to sixfold over basal levels (Ramamoorthy et al., 1998a). Extracts from $\beta$-PMA- or vehicle-treated cells were immunoprecipitated with SERT-specific antibodies, and the immune complexes were probed for PP2Ac protein. Acute treatment of cells with $\beta$-PMA had no effect on the total amount of PP2Ac but resulted in a decrease in SERTassociated PP2Ac (Fig. 4A). Pretreatment with the PKC inhibitors staurosporine (Fig. $4 A$ ) or bisindolylmaleimide I (data not shown) blocked the inhibitory effects of $\beta$-PMA on SERT/PP2Ac associations. In a recent report, we described the ability of 5-HT to attenuate $\beta$-PMA-mediated changes in SERT phosphorylation and trafficking (Ramamoorthy and Blakely, 1999). Thus, we asked whether the presence of 5-HT could also protect against the $\beta$-PMA-mediated disruption of the SERT/PP2Ac complex. Indeed, 5-HT (1 $\mu \mathrm{M})$ was able to block the $\beta$-PMA-induced loss of PP2Ac from SERT immune complexes (Fig. $4 B$ ). These findings suggest that SERT phosphorylation and trafficking in response to PKC activation may arise in part through an activity-dependent dissociation of PP2Ac from a SERT multiprotein complex. The ability of transmitter to influence PP2A associations provides a receptor-independent mechanism for transporters to constrain phosphorylation, which in turn may serve to enhance transporter surface expression. Because SERT phosphorylation and internalization is sensitive to external 5-HT (Ramamoorthy and Blakely, 1999), we suspect that a significant fraction of SERT phosphorylation occurs at the cell surface. Preliminary phosphorylation studies with biotinylated transporters are consistent with this idea (S. Ramamoorthy and R. D. Blakely, unpublished observations). PKC activation may thus trigger dissociation of the PP2Ac from a preformed plasma membrane complex, contributing to enhanced SERT phosphorylation and internalization.

\section{Norepinephrine and dopamine transporters also engage in a regulated association with PP2AC}

Pretreatment of native and heterologous NET- and DATexpressing cells with phorbol esters and OA significantly reduces catecholamine transport as seen with SERT-transfected preparations (Vaughan et al., 1997; Apparsundaram et al., 1998a). We sought to establish whether PP2Ac associations evident with SERT also occur with NETs and DATs. Treatment of slices of vas deferens, a NET-enriched preparation, with $\beta$-PMA or OA resulted in a reduction in transport activity (Fig. $5 A$ ). We sought confirmation of this finding with intact preparations using carbon fiber-based amperometric measurements of catecholamine clearance. OA treatment $(1 \mu \mathrm{M}, 30 \mathrm{~min})$ results in a decreased clearance as indicated by a reduced clearance rate and increased time course of a magnitude similar to that observed for desipramine (Fig. 5B). Moreover, immunoprecipitations of detergent extracts of vas deferens revealed the presence of NET/PP2Ac complexes (Fig. 5C). As with SERT studies, $\beta$-PMA and OA treatments of vas deferens resulted in diminished recovery of PP2Ac from NET immunoprecipitations with no effects on PP2Ac levels in total extracts (Fig. $5 C-E)$. Finally, we found evidence for DAT/PP2Ac complexes from immunoprecipitations studies of rat striatal synaptosomes (Fig. $5 F$ ). Together these findings suggest that the regulated PP2Ac associations seen with SERT proteins are applicable to other biogenic amine transporters and likely play an important role in their regulation.
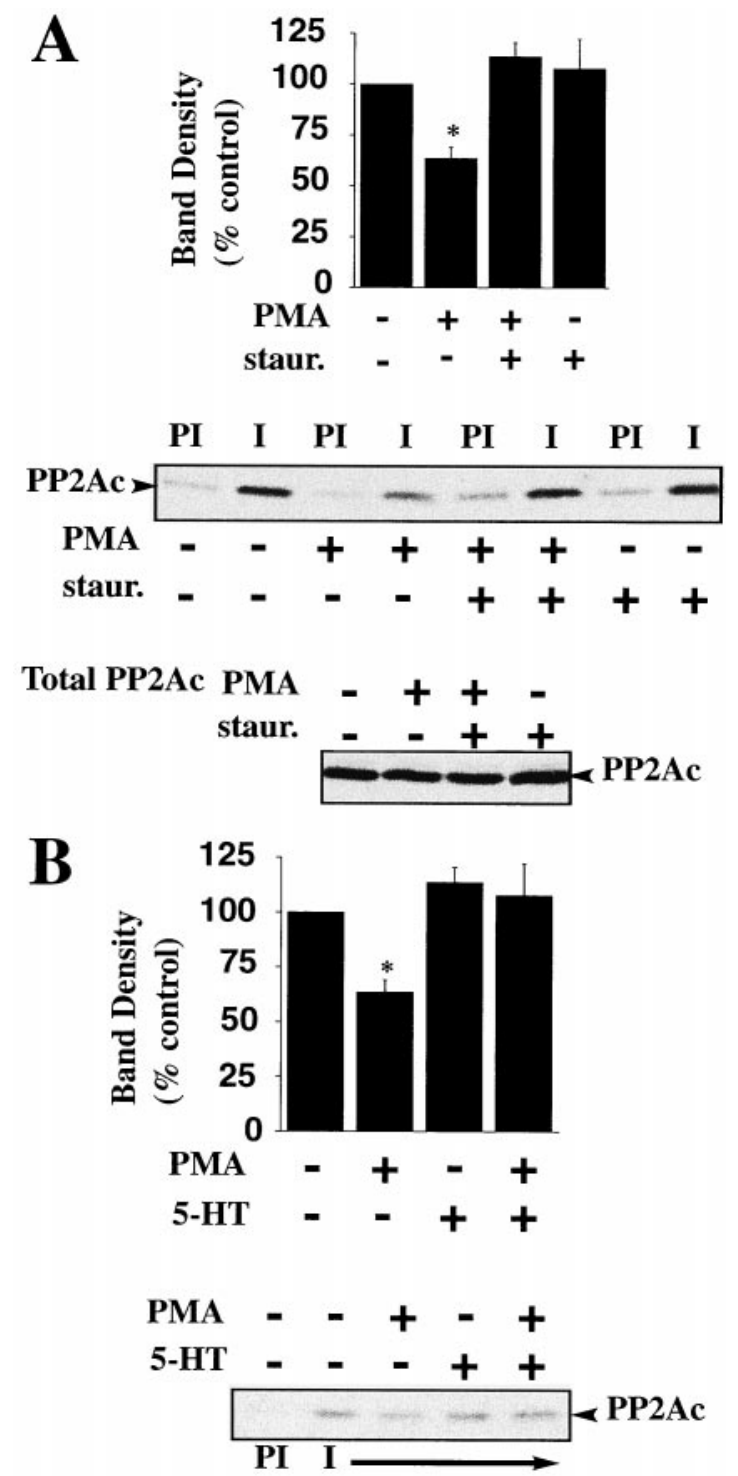

Figure 4. PKC activation disrupts SERT/PP2Ac associations. A, Treatment of cells with phorbol esters decreases SERT/PP2Ac associations. 293-hSERT cells were incubated for $30 \mathrm{~min}$ in the presence or absence of $1 \mu \mathrm{M} \beta$-PMA. Cells were solubilized and immunoprecipitated with SERT antibody (48), and the resulting blot was probed for PP2Ac as described in Materials and Methods. The PKC inhibitor staurosporine $(1 \mu \mathrm{M})$ was added $30 \mathrm{~min}$ before the addition of $\beta$-PMA. Averaged data from three separate experiments are presented \pm SEM. ${ }^{*} p<0.05$, as determined by Student's $t$ test. Representative blots are shown of SERT/PP2Ac coimmunoprecipitation using preimmune sera $(P I)$ or SERT antibody (48) from cells treated with $\beta$-PMA $(1 \mu \mathrm{M})$ or $\beta$-PMA plus staurosporine $(1 \mu \mathrm{M})$ and total cell PP2Ac under various conditions. $B, 5-\mathrm{HT}$ attenuates the $\beta$-PMA-induced decrease in associated PP2Ac. SERT/PP2Ac complexes were immunoprecipitated from 293-hSERT cells treated with 250 nM 5-HT or buffer for 20 min at $37^{\circ} \mathrm{C}$. The resulting blot was probed for PP2Ac as described. The bar plot displays averaged data from three separate experiments and are presented \pm SEM. ${ }^{*} p<0.05$, as determined by a Student's $t$ test.

\section{DISCUSSION}

In the present study, we have shown a regulated association of biogenic amine transporters with the catalytic subunit of PP2A. PP2A is known to play a role in the regulation of signal transduction pathways, in microtubule dynamics, in control of gene expression, and recently in the regulated trafficking of several membrane proteins, including the endoprotease furin (Molloy et al., 1998) and the $\beta_{2}$ AR (Krueger et al., 1997). We focus largely on SERT/PP2Ac complexes because of significant evidence for phosphorylationassociated SERT trafficking (Qian et al., 1997; Ramamoorthy et al., 1998a; Ramamoorthy and Blakely, 1999). Transporter-associated 
Figure 5. PP2Ac associates with cocaine-sensitive norepinephrine and dopamine transporters. $A$, Norepinephrine $(N E)$ uptake in rat vas deferens is sensitive to $\mathrm{PKC}$ activation and PP2A inhibition. Pretreatment of rat vas deferens slices with 1 $\mu \mathrm{M} \beta$-PMA or $1 \mu \mathrm{M}$ OA for $30 \mathrm{~min}$ significantly reduces specific NE uptake. Specific NE uptake was determined in rat vas deferens as described in Materials and Methods. Data are presented as mean \pm SEM of three separate experiments performed in triplicate. $B$, OA $(1 \mu \mathrm{M})$ treatment reduces DA clearance in rat vas deferens. Representative effect of $1 \mu \mathrm{M}$ OA (30 min) on DA oxidation signals is presented. Application and electrochemical recordings were performed as described in Materials and Methods. Darker arrow indicates time of DA application. The amplitude (micrometers), $T_{80}$ (seconds), time course (seconds), and clearance rate (micrometers per second) are $5.4 \pm 0.62,52 \pm 4.0,63 \pm 7$, and $0.22 \pm 0.01$ respectively, for controls and $5.3 \pm 0.31,68 \pm 3^{*}, 76 \pm 5^{*}$, and $0.14 \pm 0.01^{*}$ in the presence of OA. Desipramine (DMI; 1 $\mu \mathrm{M}$ ), but not $0.3 \mu \mathrm{M}$ GBR 12909, alters DA signal (amplitude, $T_{80}$, time course, and clearance rate are $5.3 \pm 0.2,42 \pm 4,59 \pm$ 3 , and $0.18 \pm 0.12$, respectively, for controls and $5.9 \pm 0.2$, $58 \pm 5^{*}, 76 \pm 5^{*}$, and $0.11 \pm 0.11^{*}$ in the presence of DMI). * indicates significant difference as compared with controls, $p<0.05$, Student's unpaired $t$ test. $C, \beta$-PMA- and OAsensitive coimmunoprecipitation of PP2Ac with NETs in rat vas deferens. Triton X-100-soluble membrane fractions were incubated overnight with NET antisera (43411), and the resulting immunoblot was probed for PP2Ac as described in Materials and Methods. Pretreatment of rat vas deferens slices with $1 \mu \mathrm{M} \beta$-PMA or $1 \mu \mathrm{M}$ OA markedly reduces association of PP2Ac with NETs, with no alteration in total PP2Ac levels. $D$, Pretreatment of rat vas deferens slices with $1 \mu \mathrm{M} \beta$-PMA or $1 \mu \mathrm{M}$ OA produces a significant reduction in the association of PP2Ac with NETs. Averaged band density \pm SEM of three separate experiments as percentage of vehicle controls is presented. Asterisks represent a significant difference $(p<0.05$ one-tailed Student's $t$ test) as compared with vehicle (Veh) controls. E, Specificity of NET/PP2Ac association. Triton $\mathrm{X}-100$-soluble membrane fractions of rat vas deferens were incubated overnight with affinity-purified 43411 NET antibody, and the resulting immunoblot was probed for PP2Ac as described in Materials and Methods. Preadsorption of antibody with immunogenic peptide abolishes the coimmunoprecipitation of PP2Ac. $F$, Immunoprecipitation of PP2Ac with DAT antisera in mouse striatal synaptosomes. Triton X-100-soluble synaptosomal membrane extracts were incubated with either nonimmune $(N I)$ or DAT-immune $(I)$ sera, and the resulting blot was probed for PP2Ac monoclonal antibody as described in Materials and Methods.

PP2Ac may control the phosphorylation state of one or more transporter-associated proteins that influence transporter intrinsic activity, cytoskeletal associations, or membrane sorting/trafficking. Moreover, because transporter phosphorylation is selectively elevated by PP2A inhibitors (Ramamoorthy et al., 1998a), PP2Ac may target phosphorylation sites on SERT itself (Qian et al., 1995a). Our ability to detect significant association of PP2Ac in the absence of transporter substrates or modulators indicates that PP2A associations are of high affinity. Significant phosphatase activity coimmunoprecipitates with SERT antibodies in comparison with preimmune and nontransfected controls. Although OA-sensitive phosphatase activity accounts for $\sim 50 \%$ of total extract phosphatase activity, all phosphatase activity recovered in SERT immunoprecipitates is inhibited by $2 \mathrm{nM}$ OA, suggesting a preferential association with PP2Ac. We also failed to detect an enrichment of PP1 immunoreactivity associated with SERT immunoprecipitations from transfected cells. The accessibility of SERT-associated $\mathrm{PP} 2 \mathrm{Ac}$ to $\left[{ }^{32} \mathrm{P}\right]$-labeled histone indicates that although the enzyme may be tightly associated, its catalytic site is exposed. In such a configuration, associated PP2Ac may be able to influence the phosphorylation state of multiple transporter cytoplasmic domains or monitor a single phosphorylated site on multiple coassembled transporter subunits (Kilic and Rudnick, 2000).

Signaling pathways downstream of activated kinases, particularly PKC, have been suggested to rapidly modulate biogenic amine transporter expression (Blakely et al., 1998). That these effects may be of physiological relevance is suggested by findings that cell surface receptors, which trigger activation of kinase pathways, can rapidly modulate transporter expression (Miller and Hoffman, 1994; Imamura et al., 1996; Apparsundaram et al., 1998a; Beckman et al., 1999; Dickinson et al., 1999). Treatments that are known to alter transporter phosphorylation, trafficking, and transport capacity result in a significant disruption of the SERT/PP2Ac complex.
PKC activation has been recognized to lead to biogenic amine transporter phosphorylation (Huff et al., 1997; Vaughan et al., 1997; Ramamoorthy et al., 1998a). We show that not only are SERTs phosphorylated as a consequence of phorbol ester application, but also that kinase activation triggers the dissociation of a regulatory phosphatase. Because we can recover SERT/PP2Ac complexes from biotinylated fractions and observe modulatory effects of transporter substrate, we propose that surface transporters are precomplexed with PP2Ac and that the disassembly of this complex, triggered by PKC activation or other modulators, may be a critical step in the regulation of transporter surface expression. Unlike transporters, $\beta_{2} \mathrm{ARs}$ associate with PP2Ac after phosphorylation-induced internalization as a mechanism for resensitization. Agonist-induced phosphorylation of $\beta_{2} \mathrm{ARs}$ results in receptor desensitization and clathrin-mediated internalization into an endosomal compartment. Receptor resensitization is believed to occur intracellularly, subsequent to dephosphorylation mediated by an OA-sensitive phosphatase with similarities to PP2A (Lefkowitz et al., 1993; Ferguson et al., 1998). The endoprotease furin complexes with PP2Ac to promote enzyme dephosphorylation and thereby dictate furin's steady-state distribution among Golgi, endosome, and plasma membranes (Molloy et al., 1998). We propose that unlike $\beta$-ARs and furin, biogenic amine transporters acquire PP2Ac before, or after insertion into the plasma membrane [or after recycling (Melikian and Buckley, 1999)], and lose this association before internalization.

Biogenic amine transporters join a growing list of membrane proteins observed to exhibit regulated associations with kinases and phosphatases (Heriche et al., 1997; Krueger et al., 1997; Westphal et al., 1998; Hsu et al., 1999; Shih et al., 1999; Westphal et al., 1999). For example, potassium channels, $\beta$-ARs, and NMDA glutamate receptors have been shown to exist in multimeric complexes containing kinases and phosphatases the enzymatic activity of 
which can modulate receptor or channel function (Heriche et al., 1997; Westphal et al., 1998; Hsu et al., 1999; Shih et al., 1999). Ratcliffe and coworkers (2000) recently described a developmentally regulated $\mathrm{Na}^{+}$channel/receptor tyrosine phosphatase complex that appears to influence $\mathrm{Na}^{+}$channel phosphorylation. Although multiple studies reveal that neurotransmitter transporters can be regulated by kinase activation and phosphatase inhibition (Huff et al., 1997; Sakai et al., 1997; Vaughan et al., 1997; Zhang et al., 1997; Beckman et al., 1998, 1999), our findings are the first, to our knowledge, to suggest that the regulation is mediated through physical associations with phosphatases that may directly influence the level of transporter phosphorylation. Regulation of this association by activated kinases such as PKC may provide a mechanism to amplify transporter phosphorylation by limiting the likelihood of dephosphorylation. Current models also posit an involvement of one or more cytoskeletal scaffolding proteins anchoring the enzymes near effectors. For example, gravin (AKAP250) was found to associate with $\beta$-ARs and is necessary, along with PP2A, for recovery from agonist-induced desensitization (Shih et al., 1999). Likewise, Yotiao, a scaffold protein was shown to physically attach PP1 with PKA and NMDA glutamate receptors to regulate channel activity (Westphal et al., 1999). It is possible that biogenic amine transporters exist in multiprotein complexes consisting of cytoskeletal scaffolding proteins, kinases, and phosphatases. Furthermore, PP2A is a multimeric enzyme composed of a structural A subunit (PR65), one of several regulatory B subunits (e.g., B/PR55, B'/PRB56,B'/PR72 and PR130), and a catalytic C subunit. Further studies are required to determine the full structural complexity of transporter/PP2Ac associations and the degree to which these associations are modulated by antidepressants (Z hu et al., 1998; Benmansour et al., 1999) or psychostimulants (Zhang et al., 1998; Ramamoorthy and Blakely, 1999). Finally, our studies raise the possibility that inappropriate or altered transporter/phosphatase complexes may contribute to transporter dysregulation described in psychiatric disorders (Ellis and Salmond, 1994; Owens and Nemeroff, 1994; Klimek et al., 1997).

\section{REFERENCES}

Apparsundaram S, Galli A, DeFelice LJ, Hartzell HC, Blakely RD (1998a) Acute regulation of norepinephrine transport: I. Protein kinase C-linked muscarinic receptors influence transport capacity and transporter density in SK-N-SH cells. J Pharmacol Exp Ther 287:733-743.

Apparsundaram S, Schroeter S, Giovanetti E, Blakely RD (1998b) Acute regulation of norepinephrine transport: II. PKC-modulated surface expression of human norepinephrine transporter proteins. J Pharmacol Exp Ther 287:744-751.

Barker EL, Blakely RD (1995) Norepinephrine and serotonin transporters: molecular targets of antidepressant drugs. In: Psychopharmacology: the fourth generation of progress (Bloom FE, Kupfer DJ, eds), pp 321-333. New York: Raven.

Beckman ML, Bernstein EM, Quick MW (1998) Protein kinase C regulates the interaction between a GABA transporter and syntaxin 1A. J Neurosci 18:6103-6112.

Beckman ML, Bernstein EM, Quick MW (1999) Multiple G-proteincoupled receptors initiate protein kinase $\mathrm{C}$ redistribution of GABA transporters in hippocampal neurons. J Neurosci 19:RC9 (1-6).

Bengel D, Greenberg BD, Cora-Locatelli G, Altemus M, Heils A, Li O, Murphy DL (1999) Association of the serotonin transporter promoter regulatory region polymorphism and obsessive-compulsive disorder. Mol Psychiatry 4:463-466.

Bengel D, Johren O, Andrews AM, Heils A, Mossner R, Sanvitto GL, Saavedra JM, Lesch KP, Murphy DL (1997) Cellular localization and expression of the serotonin transporter in mouse brain. Brain Res 778:338-345.

Bengel D, Murphy DL, Andrews AM, Wichems CH, Feltner D, Heils A, Mossner R, Westphal H, Lesch KP (1998) Altered brain serotonin homeostasis and locomotor insensitivity to 3, 4-methylenedioxymethamphetamine ("Ecstasy") in serotonin transporter-deficient mice. Mol Pharmacol 53:649-655.

Benmansour S, Cecchi M, Morilak DA, Gerhardt GA, Javors MA, Gould GG, Frazer A (1999) Effects of chronic antidepressant treatments on serotonin transporter function, density, and mRNA level. J Neurosci 19:10494-10501.

Bernstein EM, Quick MW (1999) Regulation of gamma-aminobutyric acid (GABA) transporters by extracellular GABA. J Biol Chem 274:889-895.

Blakely RD, Ramamoorthy S, Schroeter S, Qian Y, Apparsundaram S, Galli A, DeFelice LJ (1998) Regulated phosphorylation and trafficking of antidepressant-sensitive serotonin transporter proteins. Biol Psychiatry 44:169-178.

Buck KJ, Amara SG (1994) Chimeric dopamine-norepinephrine transporters delineate structural domains influencing selectivity for catecholamines and 1-methyl-4-phenylpyridinium. Proc Natl Acad Sci USA 91:12584-12588.

Cass WA, Gerhardt GA (1995) In vivo assessment of dopamine uptake in rat medial prefrontal cortex: comparison with dorsal striatum and nucleus accumbens. J Neurochem 65:201-207.

Cohen P (1989) The structure and regulation of protein phosphatases. Annu Rev Biochem 58:453-508.

Daniels GM, Amara SG (1999) Regulated trafficking of the human dopamine transporter. Clathrin-mediated internalization and lysosomal degradation in response to phorbol esters. J Biol Chem 274:35794-35801.

Deutch AY, Roth RH (1999) Neurotransmitters. In: Fundamental neuroscience (Zigmond MJ, Landis SC, Roberts JL, Squire LR, eds), pp 193-233. San Diego: Academic.

Dickinson SD, Sabeti J, Larson GA, Giardina K, Rubinstein M, Kelly MA, Grandy DK, Low MJ, Gerhardt GA, Zahniser NR (1999) Dopamine D2 receptor-deficient mice exhibit decreased dopamine transporter function but no changes in dopamine release in dorsal striatum. J Neurochem $72: 148-156$

Duan S, Anderson CM, Stein BA, Swanson RA (1999) Glutamate induces rapid upregulation of astrocyte glutamate transport and cell-surface expression of GLAST. J Neurosci 19:10193-10200.

Ellis PM, Salmond C (1994) Is platelet imipramine binding reduced in depression? Biol Psychiatry 36:292-299.

Favre B, Turowski P, Hemmings BA (1997) Differential inhibition and posttranslational modification of protein phosphatase 1 and 2A in MCF7 cells treated with calyculin-A, okadaic acid, and tautomycin. J Biol Chem 272:13856-13863.

Feldman RS, Meyer JS, Quenzer LF (1997) Affective disorders. In: Principles of neuropsychopharmacology, pp 819-849. Sunderland, MA: Sinauer.

Ferguson SS, Zhang J, Barak LS, Caron MG (1998) Role of beta-arrestins in the intracellular trafficking of G-protein-coupled receptors. Adv Pharmacol 42:420-424.

Fleckenstein AE, Pogun S, Carroll FI, Kuhar MJ (1996) Recovery of dopamine transporter binding and function after intrastriatal administration of the irreversible inhibitor RTI-76 [3 beta-(3p-chlorophenyl) tropan-2 beta-carboxylic acid $p$-isothiocyanatophenylethyl ester hydrochloride]. J Pharmacol Exp Ther 279:200-206.

Fritz J, Lankupalle J, Thoreson M, Blakely RD (1998) Cloning and chromosomal mapping of the murine norepinephrine transporter. J Neurochem 70:2241-2251.

Giros B, Jaber M, Jones SR, Wightman RM, Caron MG (1996) Hyperlocomotion and indifference to cocaine and amphetamine in mice lacking the dopamine transporter. Nature 379:606-612.

Gupta V, Ogawa AK, Du X, Houk KN, Armstrong RW (1997) A model for binding of structurally diverse natural product inhibitors of protein phosphatases PP1 and PP2A. J Med Chem 40:3199-3206.

Heriche J-K, Lebrin F, Robilloud T, Leroy D, Chambaz EM, Goldberg Y (1997) Regulation of protein phosphatase 2A by direct interaction with casein kinase $2 \alpha$. Science 276:952-955.

Hoffman AF, Lupica CR, Gerhardt GA (1998) Dopamine transporter activity in the substantia nigra and striatum assessed by high-speed chronoamperometric recordings in brain slices. J Pharmacol Exp Ther 287:487-496.

Hsu W, Zeng L, Costantini F (1999) Identification of a domain of axin that binds to the serine/threonine protein phosphatase $2 \mathrm{~A}$ and a selfbinding domain. J Biol Chem 274:3439-3445.

Huff RA, Vaughan RA, Kuhar MJ, Uhl GR (1997) Phorbol esters increase dopamine transporter phosphorylation and decrease transport Vmax. J Neurochem 68:225-232.

Imamura M, Lander HM, Levi R (1996) Activation of histamine H3receptors inhibits carrier-mediated norepinephrine release during protracted myocardial ischemia. Comparison with adenosine A1-receptors and alpha2-adrenoceptors. Circ Res 78:475-481.

Jakes S, Schlender KK (1988) Histone H1 phosphorylated by protein kinase $\mathrm{C}$ is a selective substrate for the assay of protein phosphatase $2 \mathrm{~A}$ in the presence of phosphatase 1. Biochim Biophys Acta 967:11-16.

Kilic F, Rudnick G (2000) Oligomerization of serotonin transporter and its functional consequences. Proc Natl Acad Sci USA 97:3106-3111.

Klimek V, Stockmeier C, Overholser J, Meltzer HY, Kalka S, Dilley G, Ordway GA (1997) Reduced levels of norepinephrine transporters in the locus coeruleus in major depression. J Neurosci 17:8451-8458.

Krueger KM, Daaka Y, Pitcher JA, Lefkowitz RJ (1997) The role of sequestration in $\mathrm{G}$ protein-coupled receptor resensitization. Regulation of beta2-adrenergic receptor dephosphorylation by vesicular acidification. J Biol Chem 272:5-8.

Kuhar MJ, Carroll FI, Lewin AH, Boja JW, Scheffel U, Wong DF (1997) Imaging transporters for dopamine and other neurotransmitters in brain. In: Neurotransmitter transporters: structure, function, and regulation (Reith MEA, ed), pp 297-314. Totowa, NJ: Humana.

Lefkowitz RJ, Cotecchia S, Kjelsberg MA, Pitcher J, Koch WJ, Inglese J, Caron MG (1993) Adrenergic receptors: recent insights into their 
mechanism of activation and desensitization. Adv Second Messenger Phosphoprotein Res 28:1-9.

Lesch K-P, Bengel D, Heils A, Sabol SZ, Greenberg BD, Petri S, Benjamin J, Müller CR, Hamer DH, Murphy DL (1996) Association of anxietyrelated traits with a polymorphism in the serotonin transporter gene regulatory region. Science 274:1527-1531.

Lin AM, Bickford PC, Palmer MR, Cline EJ, Gerhardt GA (1997) Effects of ethanol and nomifensine on NE clearance in the cerebellum of young and aged Fischer 344 rats. Brain Res 756:287-292.

Luo J, Pato MD, Riordan JR, Hanrahan JW (1998) Differential regulation of single CFTR channels by PP2C, PP2A, and other phosphatases. Am J Physiol 274:C1397-1410.

Melikian HE, Buckley KM (1999) Membrane trafficking regulates the activity of the human dopamine transporter. J Neurosci 19:7699-7710.

Melikian HE, Ramamoorthy S, Tate CG, Blakely RD (1996) Inability to $\mathrm{N}$-glycosylate the human norepinephrine transporter reduces protein stability, surface trafficking, and transport activity but not ligand recognition. Mol Pharmacol 50:266-276.

Miller KJ, Hoffman BJ (1994) Adenosine A3 receptors regulate serotonin transport via nitric oxide and cGMP. J Biol Chem 269:27351-27356.

Molloy SS, Thomas L, Kamibayashi C, Mumby MC, Thomas G (1998) Regulation of endosome sorting by a specific PP2A isoform. J Cell Biol 142:1399-1411.

Nelson $\mathrm{N}$ (1998) The family of $\mathrm{Na}^{+} / \mathrm{Cl}^{-}$neurotransmitter transporters. J Neurochem 71:1785-1803.

Owens MJ, Nemeroff CB (1994) Role of serotonin in the pathophysiology of depression: focus on the serotonin transporter. Clin Chem 40:288-295.

Povlock SL, Amara SG (1997) The structure and function of norepinephrine, dopamine, and serotonin transporters. In: Neurotransmitter transporters: structure, function, and regulation (Reith MEA, ed), pp 1-28. Totowa, NJ: Humana.

Pristupa ZB, McConkey F, Liu F, Man HY, Lee FJ, Wang YT, Niznik HB (1998) Protein kinase-mediated bidirectional trafficking and functional regulation of the human dopamine transporter. Synapse 30:79-87.

Qian Y, Galli A, Ramamoorthy S, Risso S, DeFelice LJ, Blakely RD (1997) Protein kinase C activation regulates human serotonin transporters in HEK-293 cells via altered cell surface expression. J Neurosci 17:45-57.

Qian Y, Melikian HE, Moore KR, Duke BJ, Blakely RD (1995a) Phosphorylation of serotonin transporter domains and their role of phosphorylation in acute transporter regulation. Soc Neurosci Abstr 21:344.7.

Qian Y, Melikian HE, Rye DB, Levey AI, Blakely RD (1995b) Identification and characterization of antidepressant-sensitive serotonin transporter proteins using site-specific antibodies. J Neurosci 15:1261-1274.

Ramamoorthy S, Blakely RD (1999) Phosphorylation and sequestration of serotonin transporters differentially modulated by psychostimulants. Science 285:763-766.

Ramamoorthy S, Giovanetti E, Qian Y, Blakely RD (1998a) Phosphorylation and regulation of antidepressant-sensitive serotonin transporters. J Biol Chem 273:2458-2466.
Ramamoorthy S, Melikian HE, Qian Y, Blakely RD (1998b) Biosynthesis, $\mathrm{N}$-glycosylation, and surface trafficking of biogenic amine transporter proteins. Methods Enzymol 296:347-370.

Ratcliffe CF, Qu Y, McCormick KA, Tibbs VC, Dixon JE, Scheuer T, Catterall WA (2000) A sodium channel signaling complex: modulation by associated receptor protein tyrosine phosphatase beta. Nat Neurosci 3:437-444.

Robinson MB (1998) Examination of glutamate transporter heterogeneity using synaptosomal preparations. Methods Enzymol 296:189-202.

Sakai N, Sasaki K, Nakashita M, Honda S, Ikegaki N, Saito N (1997) Modulation of serotonin transporter activity by a protein kinase $\mathrm{C}$ activator and an inhibitor of type 1 and $2 \mathrm{~A}$ serine/threonine phosphatases. J Neurochem 68:2618-2624.

Schroeter S, Apparsundaram S, Wiley RG, Miner LH, Sesack SR, Blakely $\mathrm{RD}$ (2000) Immunolocalization of the cocaine- and antidepressantsensitive 1-norepinephrine transporter. J Comp Neurol 420:211-232.

Shannon JR, Flattem NL, Jordan J, Jacob G, Black BK, Biaggioni I, Blakely RD, Robertson D (2000) Orthostatic intolerance and tachycardia associated with norepinephrine-transporter deficiency. N Engl J Med 342:541-549.

Shih M, Lin F, Scott JD, Wang HY, Malbon CC (1999) Dynamic complexes of beta2-adrenergic receptors with protein kinases and phosphatases and the role of gravin. J Biol Chem 274:1588-1595.

Vaughan RA, Huff RA, Uhl GR, Kuhar MJ (1997) Protein kinase C-mediated phosphorylation and functional regulation of dopamine transporters in striatal synaptosomes. J Biol Chem 272:15541-15546.

Westphal RS, Anderson KA, Means AR, Wadzinski BE (1998) A signaling complex of $\mathrm{Ca}^{2+}$-calmodulin-dependent protein kinase IV and protein phosphatase 2A. Science 280:1258-1261.

Westphal RS, Tavalin SJ, Lin JW, Alto NM, Fraser ID, Langeberg LK, Sheng M, Scott JD (1999) Regulation of NMDA receptors by an associated phosphatase-kinase signaling complex. Science 285:93-96.

Xu F, Gainetdinov RR, Wetsel WC, Jones SR, Bohn LM, Miller GW, Wang YM, Caron MG (2000) Mice lacking the norepinephrine transporter are supersensitive to psychostimulants. Nat Neurosci 3:465-471.

Zhang L, Coffey LL, Reith ME (1997) Regulation of the functional activity of the human dopamine transporter by protein kinase $\mathrm{C}$. Biochem Pharmacol 53:677-688.

Zhang L, Elmer LW, Little KY (1998) Expression and regulation of the human dopamine transporter in a neuronal cell line. Brain Res Mol Brain Res [Erratum (1998) 63:205] 59:66-73.

Zhu M-Y, Blakely RD, Apparsundaram S, Ordway GA (1998) Downregulation of the human norepinephrine transporter in intact 293-hNET cells exposed to desipramine. J Neurochem 70:1547-1555.

Zhu SJ, Kavanaugh MP, Sonders MS, Amara SG, Zahniser NR (1997) Activation of protein kinase $\mathrm{C}$ inhibits uptake, currents and binding associated with the human dopamine transporter expressed in Xenopus oocytes. J Pharmacol Exp Ther 282:1358-1365. 